\title{
Primary Squamous Cell Carcinoma of the Thyroid with Severe Tracheal Invasion: A Case Report
}

\author{
Yuichiro Iwamoto ${ }^{\text {a }}$ Takatoshi Anno $^{\text {a }}$ Katsumasa Koyama $^{\text {a }}$ Yusuke Ota $^{\text {b }}$ \\ Kazutaka Nakashima $^{\mathrm{b}}$ Yasumasa Monobe ${ }^{c}$ Hideaki Kaneto $^{d}$ Niro Okimoto $^{\mathrm{a}, \mathrm{d}}$ \\ Koichi Tomoda ${ }^{\mathrm{a}}$ \\ aDepartment of General Internal Medicine 1, Kawasaki Medical School, Okayama, Japan; 'bepartment of \\ General Surgery, Kawasaki Medical School, Okayama, Japan; 'Department of Pathology, Kawasaki Medical School, \\ Okayama, Japan; dDepartment of Diabetes, Endocrinology and Metabolism, Kawasaki Medical School, \\ Kurashiki, Japan
}

A 64-year-old Japanese man visited a hospital with symptoms of cough and wheezing. His cervical and chest computed tomography (CT) revealed a hypodense mass $(47 \times 52 \times 63 \mathrm{~mm})$ occupying from the right thyroid lobe to superior mediastinum, with compression and marked lateral displacement of the trachea to the left as shown in Figure 1a. Thyroid-associated data were almost normal: thyroid stimulating hormone, $0.429 \mu \mathrm{IU} / \mathrm{mL}$ (reference range, $0.400-6.000 \mu \mathrm{IU} / \mathrm{mL}$ ); free tri-iodothyronine, 2.49 $\mathrm{pg} / \mathrm{mL}$ (reference range, $2.50-4.20 \mathrm{pg} / \mathrm{mL}$ ); free thyroxine, $0.90 \mathrm{ng} / \mathrm{dL}$ (reference range, $0.80-1.60 \mathrm{ng} / \mathrm{dL}$ ); TgAb antibody, $<10.0 \mathrm{IU} / \mathrm{mL}$ (reference range, $<10.0 \mathrm{IU} / \mathrm{mL}$ ); and thyroglobulin, $8.89 \mathrm{ng} / \mathrm{mL}$ (reference range, 0.00-33.70 $\mathrm{ng} / \mathrm{mL}$ ). Tumor makers (CEA, CA19-9, PSA, cytokeratin 19 fragment, pro-gastrin-releasing peptide, and calcitonin) were almost within normal range. Bronchoscopy showed severe stricture of the trachea and invasion of tumor as shown in Figure 1b. In addition, histological examination of tracheal biopsy showed a highly malignant epithelial proliferation with diffuse and infiltrative features as shown in Figure 1c. Atypical cells had anisokaryosis and atypical mitoses, and some tumor cell areas presented keratinization and necrotic foci. Immunohistochemical staining showed that $\mathrm{p} 40$ was positive and p16 was partially positive. CD5 and C-kit were negative, both of which are usually positive for mediastinal tumor (data not shown).

karger@karger.com www.karger.com/etj

Karger"

GOPEN ACCESS
(C) 2020 The Author(s)

Published by S. Karger AG, Basel

This is an Open Access article licensed under the Creative Commons Attribution-NonCommercial-4.0 International License (CC BY-NC) (http://www.karger.com/Services/OpenAccessLicense), applicable to the online version of the article only. Usage and distribution for commercial purposes requires written permission.
Primary squamous cell carcinoma of the thyroid (PSCCT) is a very rare thyroid malignancy, which accounts for less than $1 \%$ of all thyroid malignancies $[1,2]$. Most patients with PSCCT have an enlarging neck mass together with dysphonia, dysphasia and/or dyspnea, although such symptoms are not obvious until the tumor becomes pretty large [3]. However, our patient did not notice his tumor by himself, although his thyroid mass became large and marked lateral displacement of the trachea to the left. In general, the invasion of thyroid cancer to the trachea is rare, but if it occurs, airway bleeding and obstruction can lead to death [4]. Most important point of this case is that subjective symptoms with PSCCT are sometimes very poor until the tumor is enlarged.

PSCCT is usually highly aggressive; its prognosis is very poor compared to other thyroid carcinomas, and a median survival time in subjects with PSCCT is as short as about 9-12 months [1], depending on the extent of the tumor resection and adjuvant radiotherapy and/or chemotherapy [5]. There is no consensus for PSCCT management and therapy because of the rarity of cases with PSCCT. Thus, complete removal of the tumor with operation has an advantage for survival, while it is considered PSCCT shows relative resistance to radiotherapy and poor response to chemotherapy [1]. Our patient's PSCCT was diagnosed as squamous cell carcinoma based on his- 

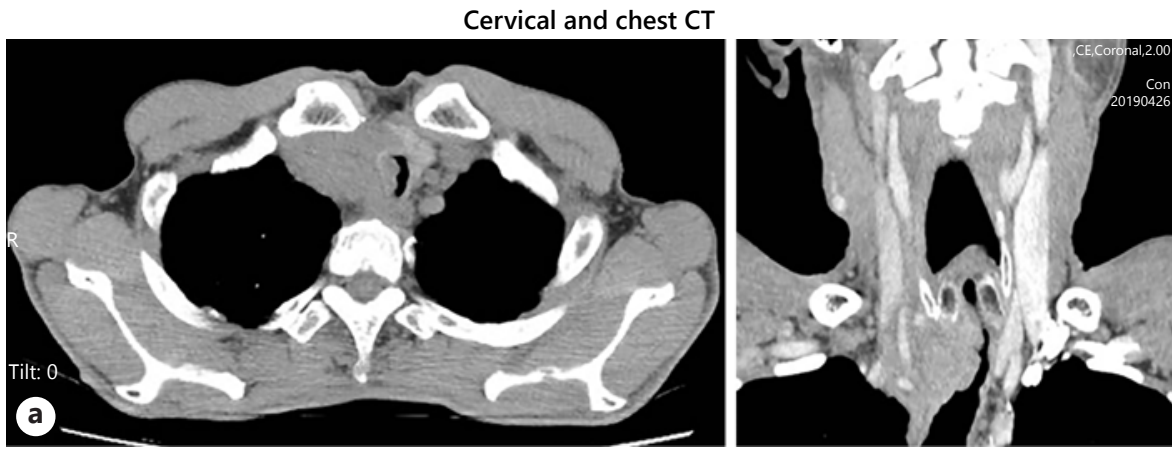

Fig. 1. a Cervical and chest computed tomography revealed a hypodense mass $(47 \times 5 \times 2 \times 63 \mathrm{~mm})$ spreading from the right thyroid lobe to superior mediastinum. This tumor was accompanied by compression of the trachea and marked lateral displacement of the trachea to the left. b Bronchoscopy showed severe stricture of the trachea and invasion of tumor. c HE staining showed a highly malignant epithelial proliferation with diffuse and infiltrative features. Atypical cells had anisokaryosis and atypical mitoses, and some tumor cell areas presented keratinization and necrotic foci.
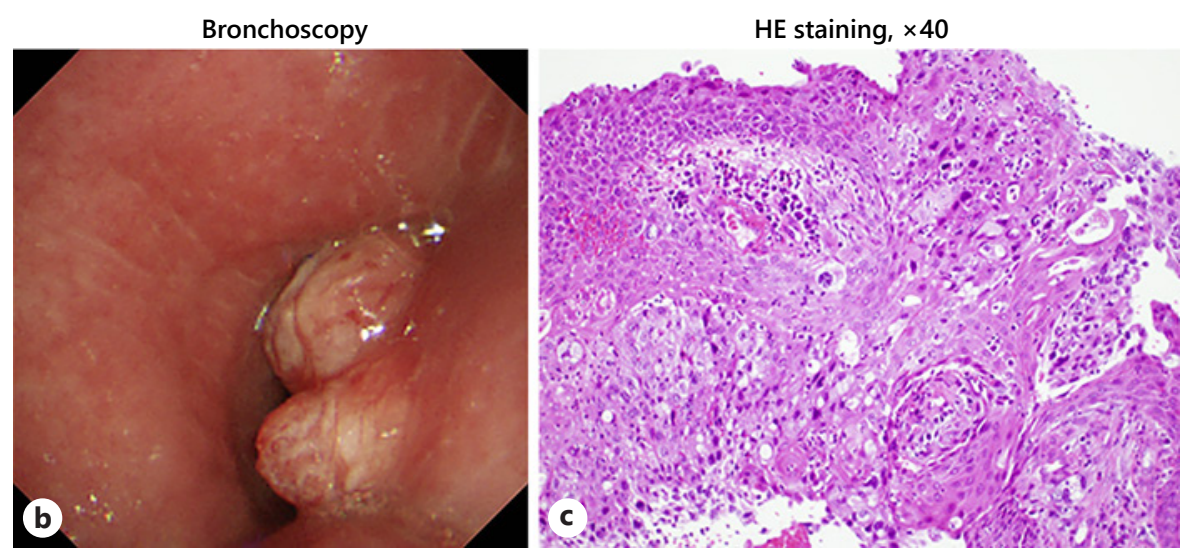

tological findings. In addition, his PSCCT was complicated with lung metastasis. Therefore, we performed radiation therapy (a total of $59.4 \mathrm{~Gy}$ ) and chemotherapy (a total of 14 courses of cisplatin and docetaxel combination therapy), which is standard therapy for squamous cell carcinoma. This therapy was pretty effective for our patient, although in general PSCCT is a highly aggressive malignancy with poor prognosis. As a result, our patient survived for more than 12 months after its diagnosis.

\section{Statement of Ethics}

The patient has given written informed consent to publish this case including the publication of images.

\section{Conflict of Interest Statement}

The authors have no conflicts of interest to declare.

\section{Funding Sources}

The author received no financial support for the research, authorship, and/or publication of this article.

\section{Author Contributions}

Y.I. and T.A. researched data and wrote the manuscript. K.K., Y.O., K.N., and Y.M. researched data and contributed to the discussion. H.K., N.O., and K.T. reviewed the manuscript.

\section{References}

Primary Squamous Cell Carcinoma of the Thyroid
1 Cho JK, Woo SH, Park J, Kim MJ, Jeong HS. Primary squamous cell carcinomas in the thyroid gland: an individual participant data meta-analysis. Cancer Med. 2014;3(5):1396-403.

2 Fassan M, Pennelli G, Pelizzo MR, Rugge M. Primary squamous cell carcinoma of the thyroid: immunohistochemical profile and literature review. Tumori. 2007;93(5):518-21.

3 Lichiardopol C, Şurlin V, Foarfă MC, Ghiluşi MC, Bondari S. Primary squamous cell carci- noma of the thyroid: a case report. Rom J Morphol Embryol. 2016;57(2 Suppl):831-6.

4 Cody HS 3rd, Shah JP. Locally invasive, welldifferentiated thyroid cancer. 22 years' experience at Memorial Sloan-Kettering Cancer Center. Am J Surg. 1981;142(4):480-3.

5 Sapalidis K, Anastasiadis I, Panteli N, Strati TM, Liavas L, Poulios C, et al. Primary squamous cell carcinoma of the thyroid gland. J Surg Case Rep. 2014;2014(12):rju133. 